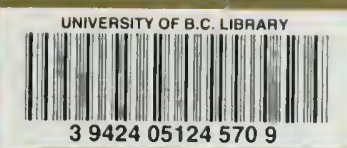

FORESTRY IN NEW ZEALAND

Statement prepered for the British Empirs Forestry Conference, Lond on July, 1920. 



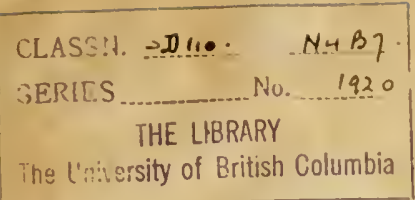

\title{
FORESTRY IN NEW ZEALAND.
}

\section{STATEMENT}

\author{
PREPARED FOR
}

\section{THE BRITISH EMPIRE FORESTRY}

\section{CONFERENCE.}

\section{London: July, 1920.}

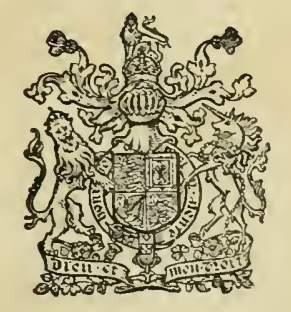


Digitized by the Internet Archive in 2010 with funding from University of British Columbia Library 


\section{FORESTRY IN NEW ZEALAND.}

Statement compiled from Official sources by Mr. W. M. E. Martin, under the direction of The Hon. Sir Thomas Mackenzie, G.C.M.G., New Zealand High Commissioner.

\section{PART 1.}

\section{A Short Gexeral Description of New Zealavi from the Forestry} PoINT OF View.

Configuration.- The main mozntain ranges of New Zealand run from the North East to the south West, and are seldom above 6,000 feet in altitude, the volcanic peaks situated outside the momtain chains reaching 9,000 feet. The upper slopes are generally covered with snow. The Southern Alps, which are noted for their wonderful scenery, are sitnated in the Sonth Island, and attain a height of over 12,349 feet. Sloping away from the momtains are Downs, seldom above 2,000 feet in height, good agricnltural lands, with fertile soils, having excellent pastures in the hilly country.

Lower beds are associated with coal measures, and sandy poor soils; in tho Nortl these are clay lands, and were once covered with vast Kauri forests, now generally called "Gim " land, owing to the fact that large quantities of Kauri "Gum " are annually dug $" 1)$ in the district.

Plains.-The plains are agriculturally the most important districts of New Zealand, the largest being in the Canterbury Plain, South Island.

Rivers.-The rivers of New Zealand are, on the whole, not large. In the South Island the main watershed is close to the coast, which transforms the rivers into mountain torrents, those flowing off on the other side being less swift. In the North Island, the rivers are less swift as the gradients to the sea are less.

Lakes.-The lakes of New Zealand are renowned throughout the world for their beauty and wonders; space forbids a description of them here, suffice it to say that there is in New Zealand every sort of lake, from the glacial lake in the South Island to the boiling lakes of the North. There are also lagoons near the seaboard, and harbours which are in reality inland lakes having exit to the sea, and which are incomparably beautiful.

Geology.-Sandstone sluales and schists form the principal mountain rocks of the country, the Gneisses being the oldest formation.

Climate.-The main features of the climate of New Zealand are :-

1. Equable Temperature.

2. Uniform Rainfall.

The mean annual temperature at Anckland, North Island, is given as 59 F., that of Dunedin, South Island, as $50^{\circ}$ F., being 13 South ; whereas that of WVellington about midway between these extremes, is given as $55^{\circ} \mathrm{F}$.

The differences in temperature on the West and East Coasts are very small.

- Rainfall.-Droughts of any severity are practically unknown in the country. The climate seems to be influenced by a succession of cyclones, travelling from West to East, the whole country being kept fairly well supplied with rain. Only in some few parts of the Canterbmy Plains, and in Central Otago, is there ever a sufficient drought seriously to affect the growth of crops. The distribution, of course, varies to some extent in the different parts of the Dominion, it being heaviest in the West of the South Island, where there is sometimes a rainfall of 200 inches annually. On the opposite coast the rainfall rapidly diminishes to less than 30 inches. In certain parts of Otago there are only about 15 to 20 inches of rain ammually. In the North Island the rainfall is more equally distributed, the greater portion having an average fall of between 50 and 70 inches per annum. In the middle of the Island the rainfall seems to be a little heavier than elsewhere.

(84857) Wt. P1240-118. 150. 1/21. Sir J. C. \& S. Gp. 32. 
Vegctation.-The general cliaracter of the New Zealand Flora is Semi-Tropical. The New Zealand Forest in its native state is almost impenetrable, owing to the number of Lianes ("Lawyers" and "Supple Jacks") whieh interlace and form an rlmost cont inums mass of vegetation. Considerably more than half of the indigenous Flora is peculiar to New Zealand, the dissimilarity of the Flora of New Zealand and that of Anstralia being the more striking considering the proximity of the two comntries.

Recent Economic Changes and Conditions.-The forester is interested in the estabJishment of timber mills in eomjunction with silviculture, and the proposed erection of plant for the manufacture of paper, also the Kauri Gum industry, whieh is now beginning to attain its old proportions. (This produet is the residum of aneient forests of Agathis Australis (Dammara), the petrified resin or "Gum" from which is dıg up on the site, and had a pre-war value of over half a million annually.)

c'oal. Oil.-Considerable quantities of coal of exeellent quality are obtained throughout the Dominion, and oil also, in varying quantities.

IVater-power. - The available water-power (some of which is used for the generation of eurrent) is considerable. 'This will be developed as time goes on.

Railuays.-There are 2,000 miles of railways in the Dominion, and several new lines are under consideration. Neans of comminieation, roads, bridges, \&e., taking the configuration of the country into account, are, on the whole, extremely good.

Posts and Telegraphs.-The post and telegraph system of the Dominion is excellent, and one of the most np-to-date, and will compare more than favourably with any other in the world: the headquarters of each forest area being in direet eommunieation with its most distant mit, and with the seat of Government at Wellington.

\section{PART II.}

\section{Description of MAIN Types OF Forest Growth.}

Of about one hundred indigenous species of forest trees, only about a dozen are of any eommereial ralue, the following being the most important :-

\section{Kauri (Agathis (Dammara) Austratis).}

This speeies is now found only in comparatively small quantities in the North Auckland District. By far the finest tree in New Zealand, it is the greatest timber producing tree in the world. A lofty moncecious tree, it is the monarch of the New Zcaland Forest, and although it does not rival the giant Sequoias of North Ameriea in its extreme leight and ciremmference, it excels them in the intrinsic value of its timber, which possesses a larger mmber of good qualities than any other pine known to commerce. The taperless bole of the Kauri enables it to produce a very large amount of timber. It is lemarkable, too, for growing to great luxuriance in inferior soils and rocky situations. The estimated contents of the Giant Kauri in the Tutamoe Crown Forest. called by the Maoris "Kairaru," is over a third of a million super feet of mercliantable timber. (Bole, I00 feet: girth, 22 feet.) The amount of Kami Forest remaining is roughly about $270,000,000$ super feet.

\section{Totara (Podocarpus Totara).}

Owing to the great demand for its timber, this speeies has been mueh reduced in quantity by milling. What remains now is ehiefly in the Auekland and Wellington bistricts. A dioecious tree, 40 feet to 80 feet or even 100 feet high, it is one of the most important in the New Zealand Forest. Its timber is elean, straight in the grain, compact, and of great durability, does not warp or twist, and is easily worked. Silviculturally, the Totara is easily enltivated, and although flourishing most luxuriantly in eool allurial soils, exhibits a great amount of indifferenee to the nature of its habitat. It may be found on sandy soils, light basaltie scoria, and stiff elays. It is oeeasionally used for ormamental planting and for hedges and breakwinds, for which purpose it is very suitable, as it bears clipping as well as the English Yew. Sometimes the vertical growth of this tree is at the rate of two feet per annum. (Kirk.) 
Matai (Polocurpus spicuta), R. Brown.

Oeenrring in most localities in the forest, Matai affords a timber of great value on account of its smooth even texture, strength and durability. It is heary and eloso grained, but is easily worked, its colour varying from a light to a full deep brown. A dioecious tree, standing 40 to 80 feet high, with an average girth of 3 to 4 feet at breast lieight.

\section{Rimu (Darydium cupressinum).}

There are in New Zealand seven of the twelve species of Dacrydium, and they are to be found nowhere besides. Dacrydium cupressinum Solander is an evergreen dicecious tree, 50 to 80 feet high or more, with weeping branches, trunk 2 to 4 feet thick, with redclish or grey bark which falls off in scales.

It is ealled the Red Pine, and ocenpies a larger area of New Zealand Forests than any other timber tree. It is very widely distributed.

\section{Kahikatea (Podocarpus Dacrydioides).}

A lofty tree so to 100 feet high, it grows all over the Dominion. Its average girth is 22 to fees. It is generally known as white pine, and is used for a great variety of purposes, including the manufacture of butter-boxes.

\section{Puriri (Vitex litloralis).}

New Zealand Oak, one of the best and most durable of New Zealand timbers. It is the strongest timber of all the indigenous broad-leaved species. A well set 11$]$ tree with spreading branches, it stands 40 to 60 feet high, and has an average girth of 2 to 5 feet. It has been much used for railway sleepers.

\section{Tawhai Rauriki (Fagus Solandri), Hook, fil. Black Birch.}

An evergreen monocious tree, 60 to 100 feet high, trunk 2 to 4 feet in diameter, bark in matured trees furrowed black. It is found mostly on hilly country. It has a hard durable timber, and is much in demand for eonstructional work of all linds, inchuding bridge-building. (This "Birch" is really a Beech.)

Tawai (Fagus Menziesii), Hook.

A fine upstanding evergreen monoecious tree from 60 to 100 feet high, with silvery whitish bark, rugose and furrowed when old. The only New Zealand species having glandular involucres, thereby easily distinguished from any other in the Dominion, although closely resembling Fagus Cunninghamii, the Tasmanian Beech. It is generally found in hilly situations in the upper parts of the forest area.

Tawai (Fagus fusca), Hook. Red Beech (Tooth-leaved Beech).

An evergreen monocious tree, 80 to 100 feet high. The timber of the toothleaved Beech is red, straight, even and compact in the grain, of great strength and toughness, and of great durability.

These three timbers are universally used for sleepers, mining, and bridge-building.

\section{PART III.}

\section{Area Covered bi Existixg Forests.}

In the early days of the Colony, the greater part of the North Island was covered by dense forest as was also an area of the South Island including the Western Coast and Southland as far as the Clutha River on the East, but the greater part of the South Island was open country. Forest fires and extensive saw milling have much reduced the area under forest. In 1886 the total area under forest was 33,120 square miles; twenty-three years later, in 1909 , the total had decreased to 26,678 square miles, amounting to a reduction of 23 per cent.

The total forest area now owned by the State is about $10,478,247$ acres, but of this area the total area of forest of milling value is approximately only $1,371,000$ acres, and a portion of this is already subject to milling licences. As the area of the whole Dominion is $65,864,550$ acres, it will be seen that the total area of forest still owned by the State is only 15.9 per cent. of the total, whilst the aroa of milling forest owned by the State is only 2.08 per cent. It may be coneluded that most of the forest on private and native lands (of which there is no information as regards the forest area) 
will be cut down in a fow rears time. When, therefore. it is borne in mind that sueh highly developed comntries as France and Germany (and even these countries import ahont 30 per cont. of their total consumption of timber) have respectively 17 per cent.

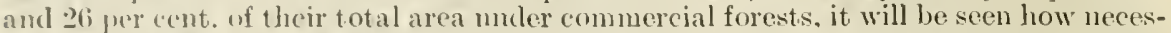
sary it is that the remaining forests in the Dominion should be subjected to such management as will prevent their wasteful nse and the exhanstion of timber-supplies.

The: following tible sets forth the area of land under cultivation, land under State Forest, and land, which is neither eultivated nor under State Forest, but which may be in occupation. It is dealt witl in the Table muler the heading of "Other" land. The land under state Forest is dealt with in two categories, that which is fit and ready for the saw and that which is not fit or ready.

TABLE 1 .

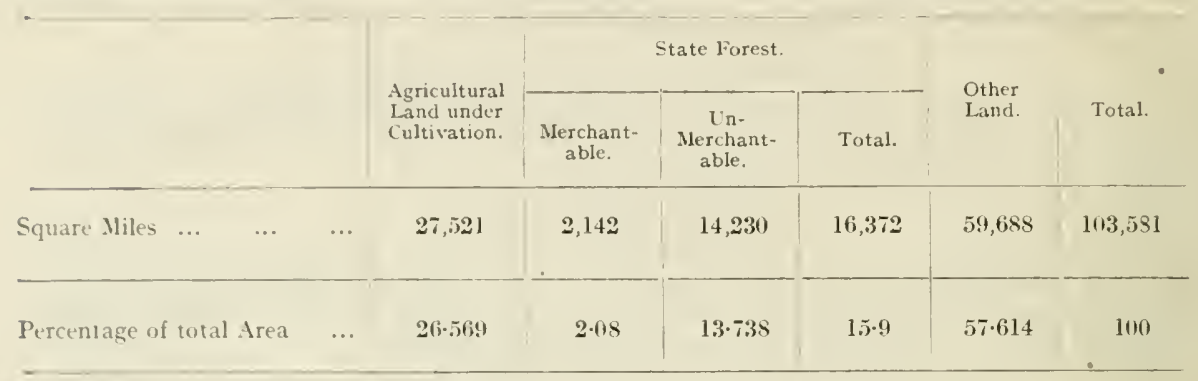

\section{PART IV.}

Brief Notes ox the Prixcipal Timbers.

\section{Kanri (Agathis Austratis).}

Kunri is usually from 80 to 100 feet high, and from 4 to 12 feet in diameter. Greatest rliameters recorded :--

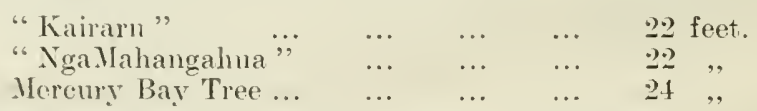

In some forest.. clmmps of trees which would afford logs from 50 to 100 feet long and 48 to for inches square, are not uneommon.

The hark is thick and resinous. A cross-section as a rule exhibits 7 to 1:3 concentrie rings to each inch of radius, therefore taking 10 rings to an inch as a fair arerage for growing timber, it would give three conturies as the age of a tree with a diameter of 5 feet at the base.

Sir D. E. Hutchins considers that Kirk"s computation of the age of the Mercury Bay 'Trec $(4,0) 0$ years) is excessive. Says he, "If the Mercury Bay Tree be divided into three periorls of $\mathrm{s}$ feet ( 12 feet radius) its age might average out as follows :-

$$
\begin{aligned}
& \mathrm{S} \text { fect diameter or } 4 \mathrm{~S} \text { inches radius, at } 10 \text { rings per inch } \quad . . .480
\end{aligned}
$$

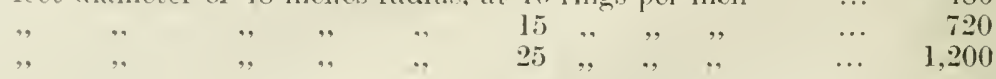

$$
\begin{aligned}
& \text {, }, \cdots, \frac{1,200}{2,400}
\end{aligned}
$$

The above scems more probable.

Kauritimber is yollowish to brown in colour, straight in the grain, even, compact, firm, clean, and silky. while it is of great strength, toughness and elasticity. It is of "xtreme clurability, and is adajted to a greater variety of uses than any other New lealand timber. "Its breaking and tensile strength are considerable, being only surpassed by piteh-pine in this respect.

Its specific graty is hetween $\cdot 495, \cdot 595, \cdot 575, \cdot 700$, for four spocinens. Breaking weight is between $165.50 \mathrm{lbs}$. and $137.17 \mathrm{lbs}$. (Balfour and Blair's Experiments.) 
Following is the Result of T'ests carried ont by Professor Percy Groom, Imperial College of Science and Technology :-

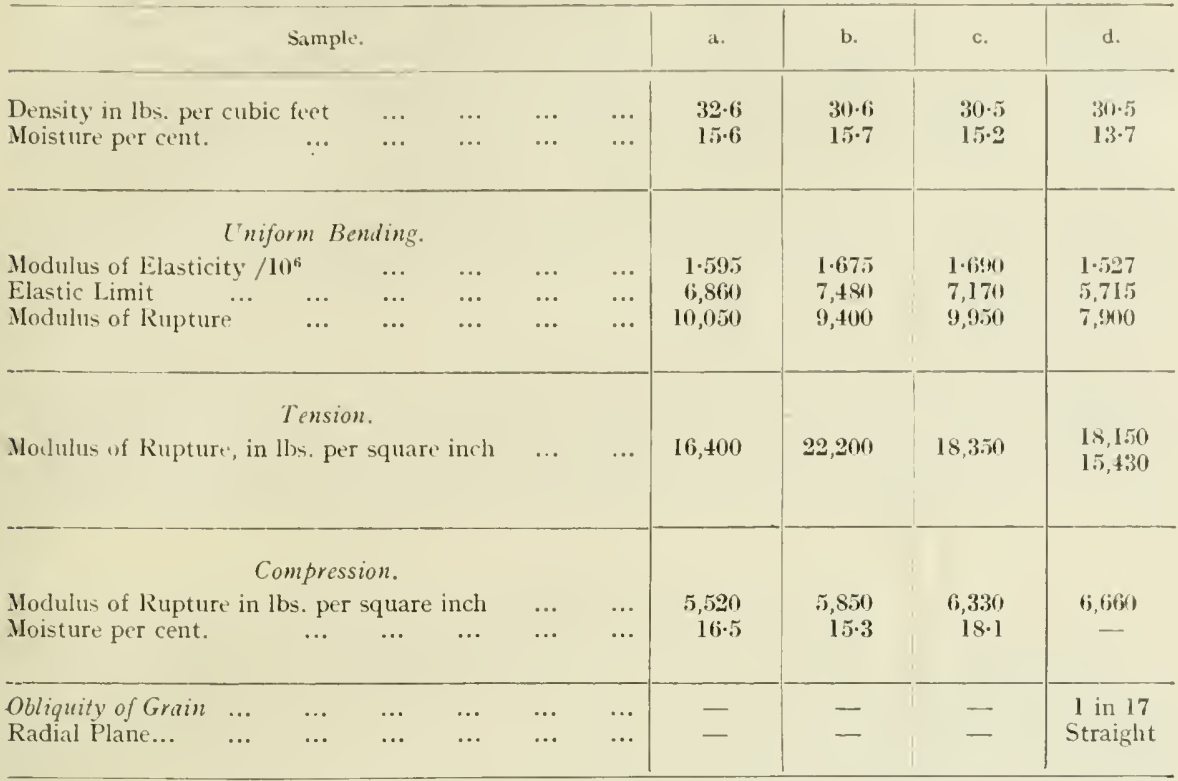

\section{Totara (Podocarpus Totara).}

The timber of the Totara tree is a deep red colour-many specimens resemblo Honduras mahogany in their general appearance. The timber is clean, straight, compact and of great durability, it does not warp or twist, and is very pleasant to work. It is an excellent timber for general purposes, building, weather-boards, sleepers, telegraph poles, also protective worlss and piers. It is remarkable for the length of time it can remain intact in the ground, and in water, and when used for marine piles, for its great resistance to the activities of the Teredo navalis. This resistance has been found to be enhanced if the timber is used whilst still green. (Kirk.) It has the disadvantage of being very brittle, which increases with age, but even with this disadvantage it is a timber of high value. Its specific gravity is .559 , the weight per cu. feet $35 \cdot 17 \mathrm{lbs}$, and the breaking weight, according to Balfour, is $133 \cdot 6 \mathrm{lbs}$. For marine piles it is superior to Kauri, but for the purposes of the shipbuilder, the other is best.

Following are the Results of Tests conducted by Professor Percy Groom, Imperial College of Science and Technology :-

\begin{tabular}{|c|c|c|c|c|c|c|c|}
\hline \multicolumn{7}{|c|}{ Sample. } & \multirow{2}{*}{$\begin{array}{r}\text { a. } \\
36 \cdot 8 \\
45 \cdot 0\end{array}$} \\
\hline $\begin{array}{l}\text { Density in lbs. per cubic foot } \\
\text { Moisture per cent. }\end{array}$ & $\begin{array}{l}\cdots \\
\cdots\end{array}$ & $\begin{array}{l}\cdots \\
\cdots\end{array}$ & $\begin{array}{l}\cdots \\
\cdots\end{array}$ & $\begin{array}{l}\cdots \\
\cdots\end{array}$ & $\begin{array}{l}\cdots \\
\cdots\end{array}$ & $\begin{array}{l}\cdots \\
\cdots\end{array}$ & \\
\hline $\begin{array}{ll} & \\
\text { Modulus of Elasticity } / 10^{6} \\
\text { Elastic Limit } \quad \ldots & \ldots \\
\text { Modulus of Rupture } & \ldots\end{array}$ & $\begin{array}{r}\text { form } \\
\cdots \\
\cdots \\
\cdots\end{array}$ & $\begin{array}{l}\text { nding. } \\
\cdots \\
\cdots \\
\cdots\end{array}$ & $\begin{array}{l}\ldots \\
\ldots \\
\cdots\end{array}$ & $\begin{array}{l}\cdots \\
\cdots \\
\cdots\end{array}$ & $\begin{array}{l}\ldots \\
\cdots \\
\cdots\end{array}$ & $\begin{array}{l}\ldots \\
\ldots \\
\cdots\end{array}$ & $\begin{array}{l}1 \cdot 182 \\
4,430 \\
7,240\end{array}$ \\
\hline \multicolumn{7}{|c|}{ Tension. } & 14,150 \\
\hline $\begin{array}{l}\text { Modulus of Rupture in lbs. pe } \\
\text { Moisture per cent. }\end{array}$ & $\begin{array}{l}m p r \\
\text { squ } \\
\cdots\end{array}$ & $\begin{array}{l}\text { ion. } \\
\text { inch } \\
\ldots\end{array}$ & $\begin{array}{l}\cdots \\
\cdots\end{array}$ & $\begin{array}{l}\cdots \\
\cdots\end{array}$ & $\begin{array}{l}\cdots \\
\cdots\end{array}$ & $\begin{array}{l}\cdots \\
\cdots\end{array}$ & $\begin{array}{c}4,310 \\
18\end{array}$ \\
\hline
\end{tabular}


Matai (Podocarpus spicata).

Matai affords a timber of grent value on aeeount of its smooth even texture, strength and durability. It is heary and elose grained but is easily worked. Its colour varien from a light to a full deep hrown. It has been stated on good anthority that. Matai is the slowest growing of all New Zealand pines, from 50 to 80 annual rings lat ring been combed in a single inch. measured near the cent re of the trunk. Instanees have been known where ss ammual rings were eomnted in 1 inel.. (N.K. Inst. Trans. Vol. IX. 18:). Its specifie gravity varies with different samples from 572 to $\cdot 792$. Its weight per enbic foot varies according to Balfour, from $34 \cdot 97$ to $49 \cdot 361 \mathrm{bs}$. Mr. Blair estimates the breaking strain at $35 t .031$ lbs. for a piece 2 fect long by 1 inch square, loaded in the middle and supported at cach cnd (13)air:s Building Materials of Otage, page $18: 2$ ).

Matai has been used for a groat ntmber of things, among these may be mentioned slcepers, flowing (Matai makes exeellent parqunt flooring), building, bridge construction, and many other uses for which a good solic timber is required of great strength and durability. The hark of Matai is sometimes used by the tanners, but not to any great extent. Its main disadrantago is that the timber is liable to shakes.

\section{Rimu (Dacrydium ('upressinum), Solander.}

Rimu logs ean be obtained of any dimensions "u, to 4 feet in diameter, and afford a handsome timber, with dark or light and sometimes yellow markings, forming a good figure. The heart of old trees is sometimes rery resinous, and affords timber of great durability for a variety of purposes. It is not, however, durable when in contact with the ground, or when too nuch exposed to the elements, as rain water finds its way in throngh the small shakes to the lieart of the log and sets up deeay. This has been found in the use of Rinu in the construction of bridges, therefore for this purpose Rimu is unsatisfactory, but for ordinary building purposes it is more generally used than any other timber throughont the Dominion. The specifie gravity of Rimu varies from 550 to $\cdot 644$ and its weight per eubie feet from $34 \cdot 28$ lbs. to $40.11 \mathrm{lbs}$. Mr. Blair of Otago states that it took a weight of $250.88 \mathrm{lbs}$. to break a ricee 2 feet long by 1 inch square, loaded in the centre and supported at both ends.

Following are Result: of Tests conducted by Professor Percy Groom, Imperial College of sicience and Technology :-

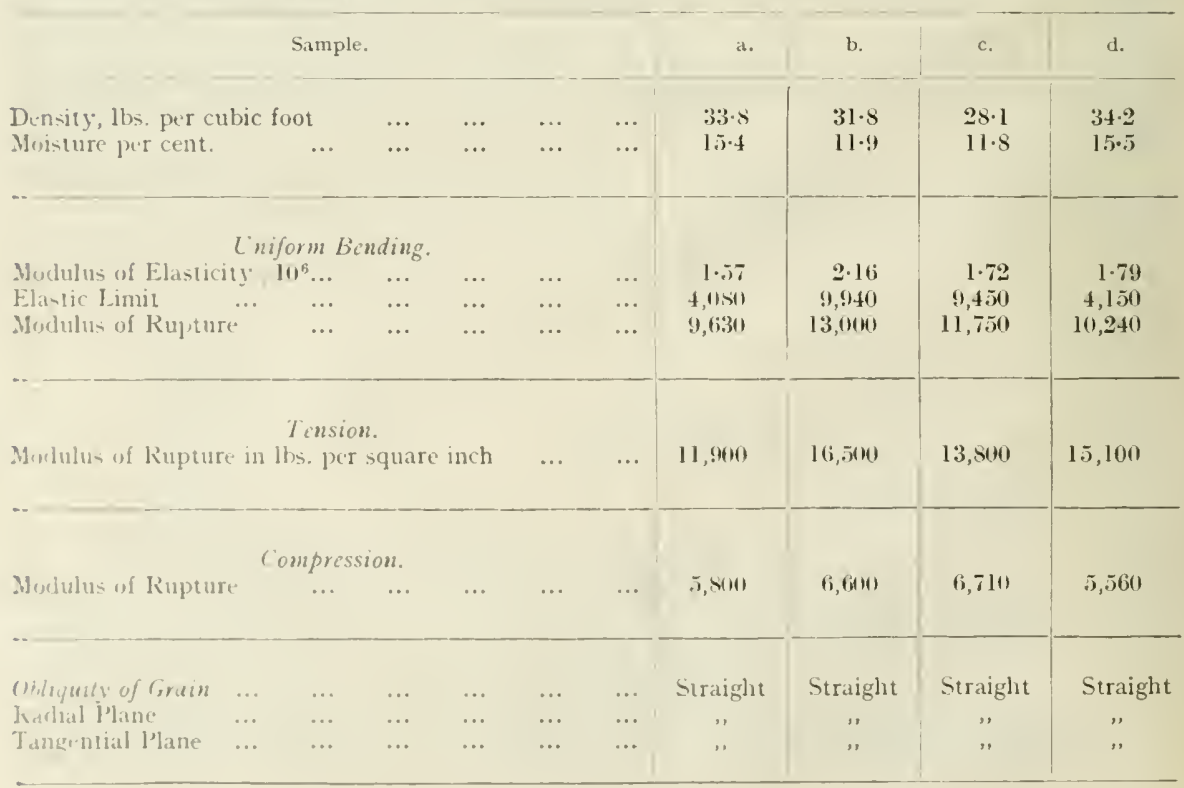




\section{Kahikatea (Podoetrpus: Dacrydioides).}

The Kalikatea attains the extreme height of 150 foot with a trunk betwoen 1 and 5 feet in diameter. The timber is whitish to palo yellow, it is firm. complact, tough. strong, straight in the grain, and of fairly even toxture, but it is not durable when in contact witl the gromel. Its specific gravity varios from +450 to $\cdot 557$. Mlany logs have the same specific gravily as water, and will only Hoat when completoly immersed. Mr. Blair of Otago stated that the weight of two pieces of green timime were 38.921 and $43.599 \mathrm{lbs}$. respectively. Mr. Balfour gave tho weight of seasoned timber as 31.54 and $29 \cdot 11 \mathrm{lbs}$. respectively, heing the a rorago weights of 10 specineslls:

As a general rule Kahikatea logs are remarkably somme ring shakes are rare, and heart shakes very small, consequently the waste in conversion is losis than in Rimu. In forming an estimate of the durability of this timber it must be remembered that it specdily decass when in inferior biological situations, and especially that when under cover, it is liable to be attacked by a small boring beetle which ruins its stability.

Following ure the Results of Tests conducted by Profensor P'. Groom. Imperial rollege. of Scitnce und Technology:-

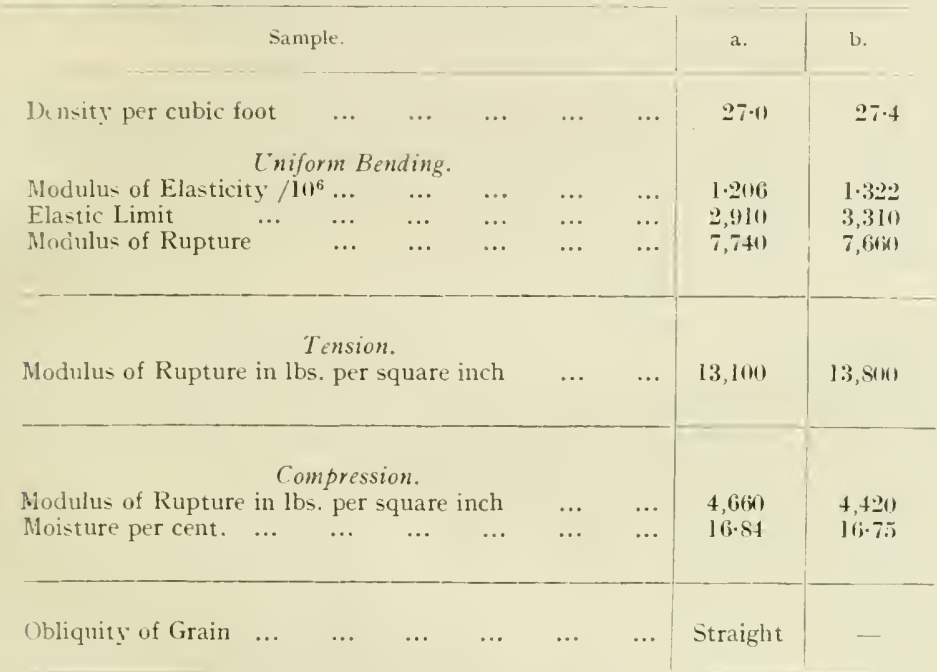

Puriri (Iritex littoralis), Cunn.

Puriri timber is of a dark brown colour, very hard, dense and heary, of great strength and durability, but as a rule difficult to work on account of the interlaced and crossed arrangement of the fibres. It is considered to be the strongest and most durable of all New Zealand timbers.

Puriri is an excellent timber for fence posts, but is getting scarce. There was a good deal of it at one time, but lack of silvieultural methods have caused its gradual decrease. Aged trees are difficult to convert, younger trees split more easily, but as a rule it is neessary to use explosive to split them. Tlie timber is used also in constructing the internal strengthening parts of boats, knees, elbows, \&e.

Tawhai Ramriki (Fagus Solandri), Hook, f. Entine-Leaved Beecls.

The timber of $F$. Solandri is of a greyish or pale red eolour, often streaked with black. and sometimes handsomely figured. The heartwood is black and very irregular in ontline. It is heary. tough and strong, and if properly selected, clurable, but the absolute necessity for rigorous selection tends to detract from its value. The weight per cubic foot in the green state is 53.485 lbs., and when scasoned, $40 \cdot 292$ lbs. The breaking weight of a piece of $F$. Solandri, 2 feet long by 1 inch square, loaded in the middle, and supported at both ends, was $339 \cdot 53 \mathrm{lbs}$.

Shrinkage: a board 12 inches wide by $\frac{1}{2}$ inch thick slurank 54 inches during seasoning period. (Blair Otago.) The question of its durability has excited considerable discussion : there need, however, be no question on this head. If felled when fully matured, and before decar commenees, it is of high value both for strength and durability. but if felled too early, or too late, it speedily perishes. (Kirk.) 
Tawai (Fagus Menziesii), Hook. f. Silver Beech.

The timber of $F$. Menziesii, or silver Becch as it is generally called in the Dominion, is of a deep red eolour, remarkably straight in the grain, even, compact hard and dense, but with very little figure. It is of great strength, very tough and elastie, but it is not durable when exposed to the weather. It is, however, very well suited for all general purposes muler cover. The weight of Silver Beech per eubic foot is $52 \cdot 621 \mathrm{lbs}$. when in the green state. and when seasoned, $38.99 \mathrm{lbs}$.; and its breaking weight is $175.5 \mathrm{lb}$.

Tawai (Fagus Fusct). Hook, f. Tooth-Leaved Beech.

The timber of the Tooth-learerl Bcech is red, straight, even and eompaet in the grain, of great strength and toughness, and of great chirahility. It is of the highest value for railway sleepers and piles for constructional purposes, whereas fences composed of this excellent timber have been known to last for forty rears. Trees that are well-grown split with the greatest ease, ant there is very little waste in eonversion.

Aceording to Balfour, the breaking strain of the timber is $202 \cdot 5 \mathrm{lbs}$. Blair of Otago gives the weight per cubic foot as $39 \cdot 620 \mathrm{lbs}$. to $68.909 \mathrm{lbs}$. in the green state, to from $31 \cdot 121$ lbs. to $40 \cdot 6+8$ lbs. in the dry state, when seasoned.

The following figures are taken from Records of Actual Tests of Neu Zealand Timbers curried out in this country on the recommendution of Professor Percy Groom, Imperial College of Science and Technology :-

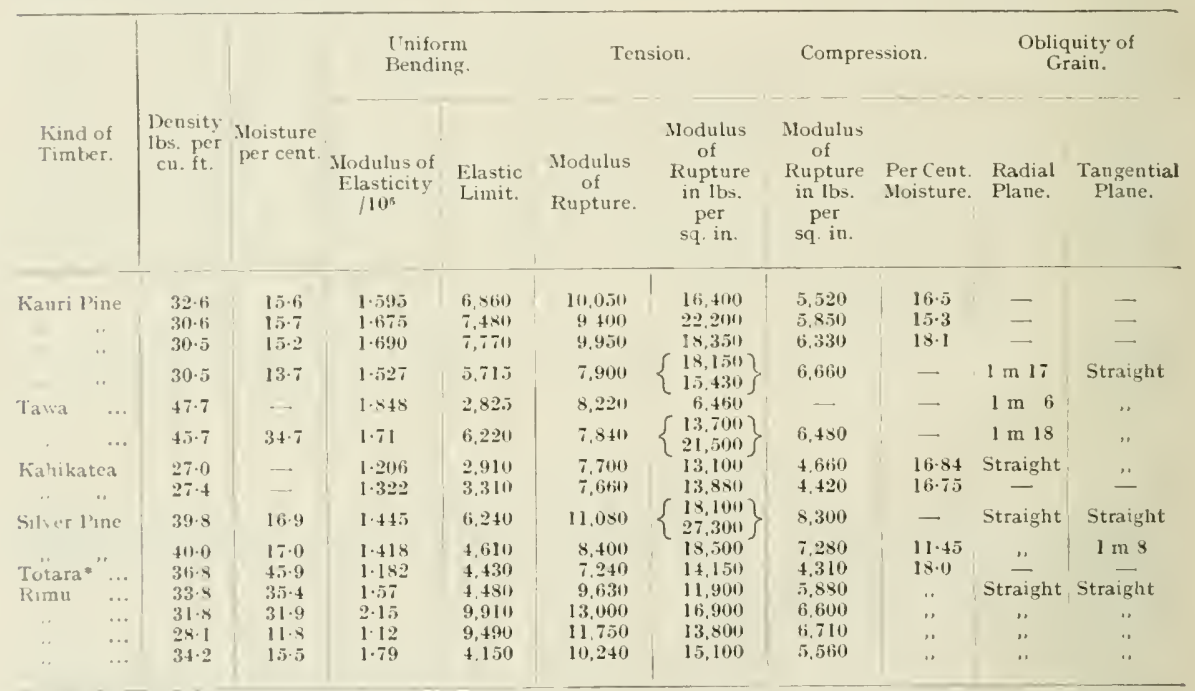

- This timber was soaking wet and therefore at its munimum strength. The true values when the wood is properly seasoned would be far higher.

\section{PART Y.}

\section{Cinssifichtion of the forest Area by OWvership.}

In 190912 per cent, of the total area of the Dominion, comprising 12,357 square miles of Crown Forest, and 3 ver eent. of the total area of the forests, comprising over 3.298 syuare miles of National Parks and permanent Reserves, were controlled by the State. The remainder of the forest in the eountry was controlled by private and Native interest.s. This amounted to 11 per cent. of the total area, or 11,023 square miles; 59 per cent. of the forest area was State controlled; the remaining 41 per cent. was in private and other hands. 
The total area controlled in 1909 by the various interests was as follows :-

Crown Forest,

Reserves, \&e..

12 per cent of total area ...

... 12,35i square miles.

Natives and Others.

3 ,

The total area controlled in 1919 by the state was $10,478.247$ acres $0116,37.2$ square miles. The proportion of this area which is ready for milling jurposes is $1.371,000$ acres, or 14,230 square miles, and part of this area is subject to milling licenses. The proportion, therefore, of the State Forosts to the whole Ioninion is 15 per cent., and the proportion of the area ready for conversion is 2.05 per cent. on the total. The War having disorganised all returns concerning forestry in the Dominion, it is regretted that there are no accurate data in this country to shew the exact present proportion of State Forests to Alienated and Native Forests. many of which are as ret unsurvered.

PART Yl.

The Relation of the State to the Forests.

A.-Brief Summary of Existing Legislation.

The State Forests Act 1908 having in several respects proved defieient, the Dominion forernment in 1918 passed an Act throngh Parliament to whieh was arlded a Section to deal with the exigeneies of the situation. This was Seetion 34 of the Wrar Legislation and Statute Law Amendment Act 1918. It empowered the Commissiones of state Forests to purchase and to hire sawmills and machinerr, to cut and sell timber in state Forests, and to purchase private lands for addition to, and protection of. State Forests. Power was also conferred upon the Gorernment to set apart any Crown Lands as, and for, "Provisional State Forests." The term "Provisional State Forests " implies that the Govemment has further powers to take back provisional forests for settlement purposes, if the oceasion demands. Everr afforestation purpose is declared to be a Public Work, under the Public ITorks Act 1908. The Gorermment is empowered to make Regulations for limiting the export of timber from New Zealand, and for prohibiting the sale of standing timber, or the granting of licenses to cut standing timber, on public or private lands except subject to conditions which nay be prescribed.

\section{B.-Brief Summary of Direct Administrative Methods of Forest Derelopment.}

With regard to Provisional State Forests, it may be pointed out that the continuous alienation of forest lands and the rapid depletion of our timber stupjies made it imperative that speedy action should be taken to eonserve as much as pu-vible of our remaining Forests. Regular forest demarcation could not be carried out inder many years, and, as a substitute, power was obtained to make " Provisional itate Forests." Lands that may be proelaimed privisional State forest will not neccrarily be permanenty locked $u \dot{p}$, for, as stated above, the reservation can be liftec by a simple procedure. No doubt many of the Reserves will contain lands suitable for settlement, and when these lands have properly been defined ther will be made arailable for settlement: but areas which are more suitable for ritention uncler forest will be liept under reservation and used for the production of timber. At the end of the rear 1919 no provisional State forests had been froclumed, but plans of areatotalling $1.800,000$ aeres (a proportion of this area is treeless mountain tops) have been received from the Distriet Offices, and these areas will shortly he proclaimed.

As the dairy, fruit, and other industries which use a large quantity of white pine were finding it quite impossible to obtain adequate supplien, measures were taken through the Board of Trade to limit the export of this timber to 40 ver cent. of the total production. This action has met with strong opposition from persons in localities where a local export trade had been worked up. but, on the other hand. the users of white pine in New Zealand hare made strong representations that its export should be entirely stopperl. Inder the authority of sub-section (6) of section $3+$ of the War Legislation and Statute Law Amendment Act 1918, regulations were published in Mlareh 1919, prohibiting the sale of standing timber, or the grant of licenses to eut standing timber on either public or private lands without first obtaining a license from the Governor-General in Couneil. 
Timber on Primete and Public Lands--Before licenses are issued under these regulations information is obtaned as to the kind and quantity of timber on the land. and the charater of the lant. In some cases, where considered advisable, a conclition that the timber shall be used solely within the Dominion is imposed. It is, of contrse, only reasemable that all forests shall be controlled by the Forestry Department. Which exists solely for the purpose of managing forests efficiently, and will have the traines stafl nectssary for that purpose. It will certainly be one of the duties of the forestry stafl to make sure that the forests are so managed that there will be ample supplies of timber both now and in the future for mining and for other purpuses.

Forest Fires. During the year 1919 very little damage was done to state forests by fire. Two hundred acres were burned in Canterbury, but this forest contained no timber of milling value. On ('rown land adjoining the W'aipona State Forest 200,000 feet of Kauli was destroyed hy fire, lut the fire was put out before it reached the reserve. At some of our most important Kanri forests there are already caretakers but more rangers are required : and it is drirable to have new legislation to control burning by settler's, to extend the powers of forest officers, and to make obligatory the use of "spark-arresters" fluring slummer months. In common with most young conntries. New \% Haland has lost thongh the ravages of fire large areas of forest the value of which, if now existing. would amount to many hundreds of thousands of pouncls.

Fir Protection.-Persons are often heard to assert in New Zealand that Bush fires are maroidable, that they oceur spontaneously, and cannot be guarded against, but such assertions are mreasonable when it is remembered that effective fireprotection is practi-ed in sweden. Norway, Germany. France, Austria, India, Japan and south Africa, where the summers are hotter and drier on the whole than they are in New Zealand. Protection against Forest Fires is simply a matter of proper methods and adequate staffs. Even in forests where fire protection is practised, fires occasionally do oecur-as they do in cities where fire brigades are liept, but in the former case there is no more reason for aecepting fires as maroidable than there is in the latter ease.

Planting of Ilaste Areus. - There is a large area of Bush land in New Zealand which is at present of little or no value but which, on account of its growing on poor hilly country it is desirable to retain under forest. By interplanting valuable species on these hilly sites, these areas can be rendered directly valuable, and ean be made to produce good timber at the end of a rotation. With this method only 200 trees are planterl to the acre, as against 2,700 in plantations in open country. Experiments have been made in the Dominion with Monterey Cypress, and so far have given every satisfaction. Experiments are being conducted in North Island and also in the South Island.

Experiments will also be made in the restoration of worked out milling forest by means of natural regeneration : but at present the officers with sufficient training to undertake this work are already fully occupied with other work.

\section{C.- Brief Summary of Assistance given to Forestry.}

The total number of trees disposed of to farmers and local bodies during 1919 was 420.412 . Which is an increase of 159.412 over the number disposed of for the provious year. Inasmuch as tree planting will supplement the timber supplies of the Dominion, will ard greatly to it; heauty: and will tend to improve the climatic conditions, there should be no question as to the advisability of the State encouraging it by di-pesing of trees at a low price. In many countries notably Canada, South Africa, ancl some of the Australian States, tree planting by settlers has been considered so dererving of enconragement hy the ritate, that trees have for many years been dispuscel of. cither at a low price or gratis. The best results have, however, been obtainel in those, state's where a small charge is made for the trees, as it has been found that where tree are given free of all charge settlers are liable to take no care of them.

Discharyed soldiers in Plnutations.-During the first half of 1919 labour was scarce. To make plantation work more attractive to discharged soldiers huts are built in the various plantations and every convenience supplied. Until recently most of the soldier workers have suffered from somo physical disability, but latterly men in better health have accepted employment. The eost of work done by soldier labour 
has exceeded the cost of similar work done by other labonr in other Incalities. During 1918-1919 over 22,500 trees were supplied to returned soldiers free of all charge for planting on their own lands.

State Nurseries.-During the year ending 31 st Mard, 1919, 3,231,275 trees were raised in the four State Nurseries: and during the sime period 4,384,036 trees wero sent ont to the varions State plantations, and also 453,749 trees to ontside places. In spite of a shortage of labour and a depleted staff, the new area planted was 2,799 acres, which brings the total area planted, since afforestation was first started in 1896 , to over 35,158 aeres.

NORTH ISLAND.

\begin{tabular}{|c|c|c|c|c|c|c|c|c|}
\hline $1910-11$ & $1911-12$ & $1912-13$ & $1913-14$ & $1914-15$ & $1915-16$ & $1916-17$ & $1917-18$ & $1918-19$ \\
\hline Acres & Acres & Acres & Acres & Acres & Acres & Acres & Acres & Acres \\
\hline 1,575 & 1,664 & 776 & 1,288 & 1,416 & 1,913 & 1,918 & 1,633 & $1,83.5$ \\
\hline
\end{tabular}

Total $\quad \ldots \quad \ldots \quad \ldots \quad 23,627$

SOUTH ISLAND.

\begin{tabular}{l|l|l|l|l|l|l|l|l|l}
\hline 1,025 & 902 & 828 & 537 & 749 & 764 & 846 & 1,020 & 964 \\
\hline
\end{tabular}

Total $\quad \ldots \quad \ldots \quad \ldots \quad 11,817$

North and South Islands--Total $\ldots \quad 35, \mathbf{4 4 4}$

\section{PART VII.}

The Forest Authority.

Origin.-In the early days of the Colony, one of the first methods of inducing the planting of suitable trees, was by means of "land grants" - a settler being given a free grant of Crown Land if he planted a certain proportion of his lands with trees. In Canterbury, where the system came into force in the early " seventies " as much as two acres of Crown lands for one acre of plantation put down, was granted, and every indncement was given to the settlers to put their land under plantations. Several large plantations may beseen in Canterbury that were established by means of this method, and settlers are now, in many instances, getting good returns for their timber, the $P$. Insignis trees being cut down for their timber. As, however, the system leferred to did not meet the growing requirements of the country, it was discontinued, and it came to pass that the methorls of State Afforestation that had proved so successful in older comntries eventually came to be adopted in New Zealand.

Plantations. - As a first step, three experimental stations were selected where plantations of various trees, aggregating about 15 aeres, were started by the Government on the Kaingaroa Plains, between Tanpo and Rotorua. Other small plantations in the surrounding district, aggregating a further twenty odd acres, were started.

Encouraged by the success of these preliminary experiments, a Forestry Branch of the Department of Lands was started in 1896, and three Nurseries were established at Tapanui, Ranfurly and Whakarewarewa. Later on, another was started in the Canterbury District at Hanmer. In 1919 the urgent needs of the rapidly dwindling forest resomces of the Dominion impelled the creation of a separate Department of Forestry. This Department will be under the direction of a Director of Forests, who 
will have the assistance of Research Officers, Forest Inspectors, and such other statf as may he necessily. Tho Ministerial head of the Department is the Commissiener of Sitate Forestis.

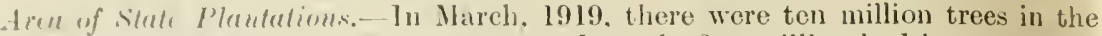
fomp mursies of the Folestry lopartment. and nearly five million had been sent out durine the preceding twelve months. A total area of $35,3+4$ acres had been planted with serenty-five million trees in State plantations. the adclition for the year being

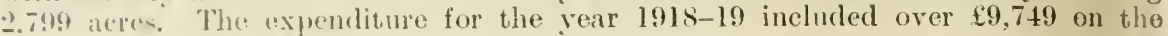
mursories and $22.5 .(1)$ ti an the plantations.

D)isstmination of Forentry Information.-Great crestit is due to the Now Zealand Forestry league fol the enterprise it has shown in disseminating leaflets giving information on rarions matters in comnection with Forestry, and advocating that onr foress (the ne'cesity of which to a comntry has been emphisised by the war) should Lesulijecterl to sejentifie management. In Australia and Canada the Forestry Leagues receive ofticial reconnition and support, and they do most useful work in spreading information as to the great value of forests to a country. and the necessity for their frofrel management. itilimation and conservation. There is much need for propaGancla on Forestry in Non Zealand, and it is to be hoped that the New Zealand Forestry Leenese will continne and extend the useful work it has started there.

\section{PART X.}

\section{RESEARCH.}

During the vear past there was considerable controversy as to the rate of growth of incligenous trees as compared with that of exotic trees. Excepting in the cases of Pinus Rudinlu and the Eucalypts, there is no reliable information as to the rate of growth to a millable size of exotics in New Zealand when planted in large areas. Many people have quoted the increments male by certain exotics grown as singlo trees or in rows as wind breaks on good land, as conclusive proof that such trees should be grown for timber in plantations on open lands in preference to any attempt to regenerate indigenous forests. Such a conclusion is, however, not warranted from such evirlence. As the growtl of single trees of a particular species is no criterion of the arrage growth of that species when it is grown in a clense stand on poor land which, it may here be sajd. is the only laud on which forestry should be practised on a commercial scale. As an instance of the truth of this may be given an eleven-year-old flantation of the pulck-growing Pinus Padiala at Hanmer, in which the trees were planted + feet ly 4 feet apart : the average diameter at breast height, under the hark of the interior trees was onl $3_{4}^{3}$ inches, with a height of approximately 40 feet, whilut tho same trees grown in single rows might be as much as 11 inches in diameter at the same age. As regards the rate of growth of indigenous trees in the natural fnrent. rery few ohiervations liave been made by competent observers.

Jirmuler (iromth of Kumri.-Mr. T. F. Cheeseman, F.L.S., has done some valuable work in connection with the Kauri and has shown that the diameter growth (inching trees up to 70.5 years olel) is 4.8 years to 1 inch. From measuroments that have been made on thee lianris. and a number of boards, the average cliameter inerement nbtaimed was 1 inch in $4 \cdot f$ vears. whilst one board 8 inches wide showed an increment it the rate: of 1 incle of cliameter in $3 \cdot 6$ years. One of the quickest growing Kauris oherevel by Mr. ('heseman was 11 feet in diameter, and it had reached this at an averace ritc of 1 inch in $3 \cdot 6$ vears, which is probably not surpassed, if equalled, by any of the first-chss conifers in natural forests in any part of the world. In the case of $K$ 'nuri. when eompared with trees in planted forest it must be borne in mind that it ha-to contend with the unchecked competition of other trees surrounding it, whereas t.rum in a cultivater forest are for the wholo period of their growth under the managemint of skilled foresters.

Dinneler of Imdigenons Trees.-Little has yet been done to obtain the true diameter increment of wther native trees. Neasurements have, however, been made, which indicate that the Beeches and Tanekaha (Celery pine) are both fairly fast, that Pimu and Totara. though in early life slow, quicken as their crowns get to the light, 
that White Pine is slow, and that Matai, Nilver Pine, and Mountain Cedar are all very slow. Some Matai and Silver Pine have been observed to have taken 50 years to grow 1 inch in diameter. It can, however, be reasonably assumed that the rate of growth of all indigenous trees in the forest can be aecelerated hy the application of silvicultural methods. It is, of course, absurd to condemu the natural regeneration of indigenous forests because some of the biggest Kauri trees are I,000 years old. It is of little consequenee in Forestry if a tree 12 feet in dianeter has taken 500 or 1,000 years to grow, but it is of great consequence how long a tree takes to reach the smallest diameter at which it ean be profitably milled. The Californian Red-Wood is a very quick-growing tree, and one that is undoubtedly profitable to regenerate, yet it is one of the oldest trees in the world, some specimens having been found by American scientists to be over 4,000 years old. A research officer is shortly to be appointed to the staff, and one of his first dities will be to make a eomprehensive investigation of the diameter, height and volume, and increment, of onr elicf trees thronghout the whole of the Dominion.

Sir D. E. Hutehins has written a vahable and exhanstive report on his investigations into the growth of the Kauri. He strongly maintains that a continnous production of timber can be secured from a Kauri forest, and that such production is cheaper than the production from trees grown in plantations. He is satisfied that a very great mistake has been made in New Zealand in allowing the clear felling of Kauri and the subsequent ntilisation for farming of the poor land on which it grew.

\section{PART XI.}

AnNual InCrement.

It is not possible at present to give an estimate of the annual increment of the New Zealand Forest. Many of the Forests are still unsurveyed, henee there are no accurate data upon which to base an estimate.

Note:-No information has been supplied under the following Sections:-

\section{Section}

VIII. Forestry Activities of Corporate Bodies and Private Individuals.

IX. Professional and other Societies interested in Forestry.

XII. Forest Industries.

XIII. Exports and Imports of Timber.

XTV. Summary and Ontlook. 
in wo hock is igor use in Library Evildoing ONLY and as a "Reserved" Loan 


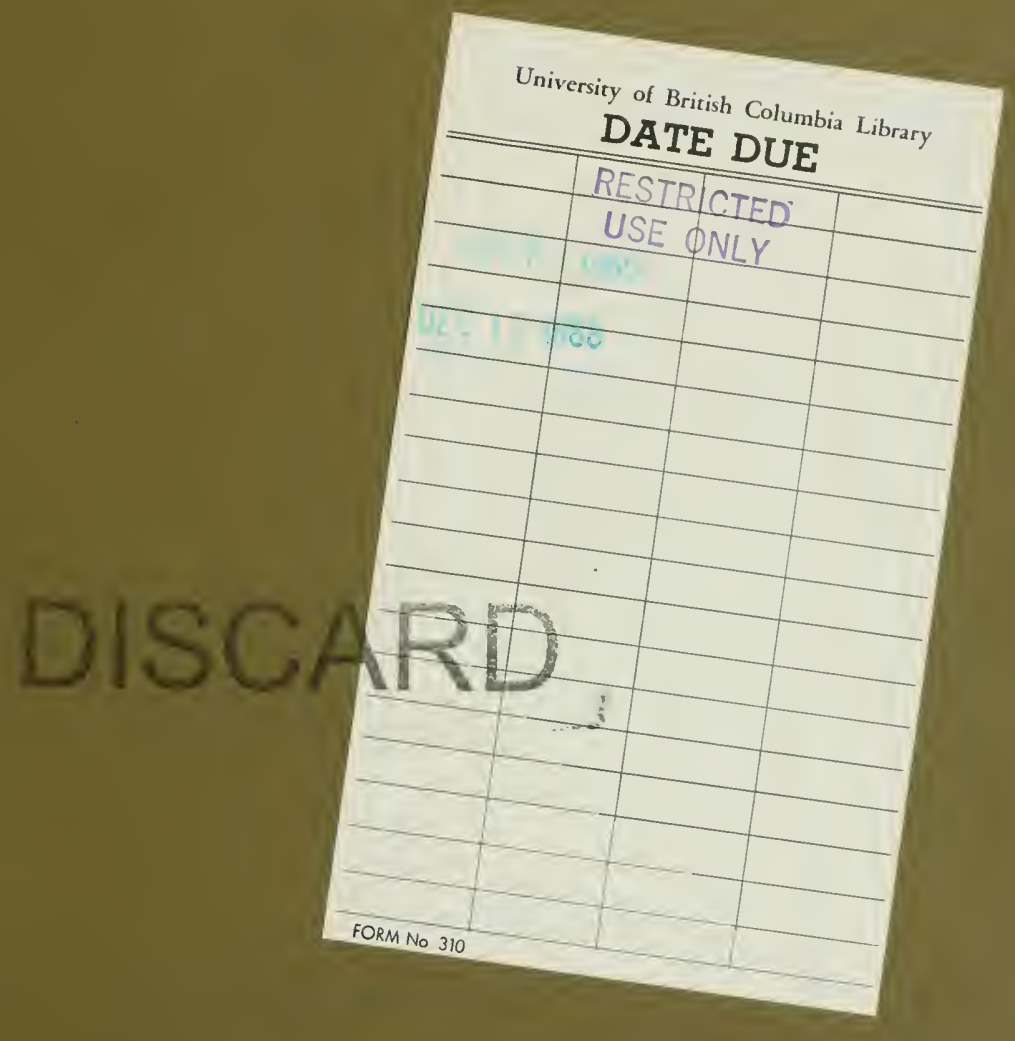


